\title{
Cellular immune response of Curraleiro Pé-duro and Nellore calves following Mycobacterium bovis-BCG vaccination ${ }^{1}$
}

\author{
Mayara Fernanda Maggioli², Joyce Rodrigues Lobo², Maria Clorinda Soares \\ Fioravanti ${ }^{2}$, André Kipnis ${ }^{3}$ and Ana Paula Junqueira-Kipnis ${ }^{3 *}$
}

\begin{abstract}
Maggioli M.F., Lobo J.R., Fioravanti M.C.S., Kipnis A. \& Junqueira-Kipnis A.P. 2013. Cellular immune response of Curraleiro Pé-duro and Nellore calves following Mycobacterium bovis-BCG vaccination. Pesquisa Veterinária Brasileira 33(12):14031408. Laboratório de Imunopatologia das Doenças Infecciosas, Instituto de Patologia Tropical e Saúde Pública, Rua Delenda Resende de Melo s/n, Setor Universitário, Goiânia, GO 74605050, Brazil. E-mail: apkipnis@gmail.com

The present study aimed to assess the CD4, CD8 and $\gamma \delta$ blood levels for Curraleiro Pé-duro, as well as the specific IFN- $\gamma$ response after BCG vaccination using flow cytometry. The specific immune response against BCG was also evaluated by tuberculin skin test, performed before and 45 days after the vaccination. For comparison purposes, the same parameters were investigated on Nellore calves, an exotic bovine with resistance previously demonstrated. Naturally, Curraleiro Pé-duro animals had greater levels of CD4, CD8 and $\gamma \delta$ lymphocytes $(\mathrm{p}<0.05)$. In response to vaccine, Curraleiro Pé-duro showed greater ability to respond specifically to BCG, generating resistance profile (Th1), evidenced by greater number of antigen specific CD4+ cells producing IFN- $\gamma(\mathrm{p}<0.05)$ and also higher tuberculin skin test reaction $(\mathrm{p}<0.05)$. Additionally, vaccinated Curraleiro Pé-duro calves had higher CD4 cells numbers than both Nellore control $(p<0.05)$ and vaccinated groups $(p<0.05)$. Curraleiro Pé-duro calves' higher basal lymphocytes blood level and stronger response in both IFN- $\gamma$ and tuberculin skin test parameters probably play a positive role on protection/ resistance to Mycobacterium bovis.
\end{abstract}

INDEX TERMS: Mycobacterium bovis-BCG vaccination, bovine resistance, tuberculosis, flow cytometry.

RESUMO:- [Resposta imune celular de bezerros Curraleiro Pé-duro e Nelore após vacinação com Mycobacterium bovis-BCG.] 0 presente estudo teve como objetivo avaliar níveis sanguíneos de células CD4, CD8 e $\gamma \delta$ no sangue periférico de bezerros Curraleiro Pé-Duro, bem como a produção específica de IFN- $\gamma$ por essas células em resposta à vacinação com $\mathrm{BCG}$, através de citometria de fluxo. $\mathrm{A}$ resposta imune específica contra BCG também foi avaliada por teste tuberculínico, realizado antes e 45 dias após a vacinação. Para fins de comparação, os mesmos parâme-

\footnotetext{
${ }^{1}$ Received on September 12, 2013.

Accepted for publication on December 13, 2013.

${ }^{2}$ Escola de Veterinária e Zootecnia, Universidade Federal de Goiás (UFG), Rodov. Goiânia-Nova Veneza Km 8, Cx. Postal 131, Campus Samambaia, , Goiânia, GO 74001-970, Brazil.

${ }^{3}$ Laboratório de Imunopatologia das Doenças Infecciosas, Instituto de Patologia Tropical e Saúde Pública, UFG, Rua Delenda Resende de Melo s/n, Setor Universitário, Goiânia, GO 74605050, Brazil. *Corresponding author: apkipnis@gmail.com
}

tros foram investigados em bezerros da raça Nelore, uma raça bovina exótica com resistência demonstrado anteriormente. Naturalmente, animais da raça Curraleiro Pé-Duro apresentaram maiores níveis de CD4, CD8 e linfócitos $\gamma \delta$. Em resposta a vacina, Curraleiro Pé-duro mostrou maior capacidade de responder especificamente ao BCG, gerando perfil de resistência (Th1), evidenciado pelo maior número de células CD4+ específicas produtoras de IFN- $\gamma$ e maior reação cutânea a por tuberculina. Os maiores níveis basais de linfócitos, maior produção de IFN- $\gamma$ e reação cutânea à prova tuberculínica provavelmente desempenham um papel positivo na proteção/resistência ao Mycobacterium tuberculosis.

TERMOS DE INDEXAÇÃO: Vacinação com Mycobacterium bovis-BCG, resistência bovina, tuberculose bovina, citometria de fluxo.

\section{INTRODUCTION}

Brazilian cattle are descendant of European bovines (Bos taurus) brought to the country in the 16th century. The ini- 
tial place for cattle breeding was the Northeast of Brazil, because settlers first colonized this region. Progressively, the herd became widespread in the different ecosystems around the country. During five centuries the European cattle underwent natural selection in those specific environments originating four new bovine breeds showing unique adaptive traits for different backgrounds. Curraleiro Pé-duro was the first bovine breed arisen in Brazil, since it was based where the settles introduced the breeding (Mariante \& Egito 2002, Serrano et al. 2005, McManus et al. 2011).

During the last century, exotic breeds were introduced in Brazil aiming the increase of the commercial production. In general, Indian breeds were more suitable than European breeds. Nellore (Bos indicus) animals are adapted to tropical conditions, less affected for several diseases and parasites and less exigent than European breeds (Bianchini et al. 2006, Oliveira et al. 2009, Abelli et al. 2010). Despite their meat characteristics (such as pour tenderness and marbling potential), Nellore breeding is advantageous and currently this is the main breed for beef in Brazil (Moura et al. 2011).

The exotic bovines replaced Brazilian breeds and Curraleiro Pé-duro is now under risk of extinction (FAO 1995). In 2010, only 3,692 Curraleiro Pé-duro animals were cataloged (Fioravanti et al. 2011). Since 1983, the Brazilian government designed a program (Brazilian Animal Genetic Resources Conservation Programme) seeking the protection of animals, including Curraleiro Pé-duro. The program encourages the research of traits involved with the rusticity and resistance and alternatives for its utilization (Mariante \& de Bem, 1992). Additionally, three main objectives have been supported: the reintroduction of Curraleiro Pé-duro breeding in the subsistence farming in semi-arid regions (where breeding of more exigent bovines is not possible), establishment of geographic identification seals for helping the development of commercial niches and stimulation of cross breeding with other breeds (McManus et al. 2005).

Today, Curraleiro Pé-duro is found in the Cerrado (a savanna enviroment in the Central region of Brazil) and Caatinga (Brazilian semi-arid region). The general weather conditions in these regions are hostile for large mammals, mainly in the Caatinga area. Elevated annual temperature $\left(27^{\circ} \mathrm{C}\right)$ and dry weather $(750 \mathrm{~mm} /$ year $)$ lead to scarcity of pasture for long periods. Further, the semi-arid region poverty makes health and nutritional care for animals minimal or nonexistent at all. The bovine originated in this scenario is highly rustic and believed to be more resistant (Serrano et al. 2004, Mariante \& Cavalcante 2006, Azevêdo et al. 2008, McManus et al. 2011). So far, a single study, Moraes et al. (2009), provided some physiological aspects of Curraleiro Pé-duro calves showing that Curraleiro Pé-duro animals presente increased levels of total leukocyte in the bloodstream. However, whether those observations are related to the resistance and consequently the immune response to a specific agent was not addressed.

The Mycobaterium bovis Calmette-Guerin (M. bovis-BCG) is a live attenuated vaccine derived from the virulent agent of bovine tuberculosis (bTB) generated in 1919. BCG is currently used for human vaccination against tubercu- losis (TB) and experimentally used in cattle (Buddle et al. 2005, Kaufmann et al. 2006). The BCG vaccination elicits strong cellular mediated immune (CMI) response without causing clinical disease (Waters et al. 2009, Whelan et al. 2011, Chan et al. 2013). The main tools for human and bovine TB diagnosis are tuberculin skin test (TST) reaction to purified protein derivated from $M$. bovis culture (bPPD), as well as, specific IFN- $\gamma$ production (i.e., T helper 1 response, Th1) after antigenic stimulation. These tests are also useful to access the immune response progression on vaccine researches (Buddle 2010, Nema 2012, Thom et al. 2012). Therefore this well established model seems very suitable to further investigate Curraleiro Pé-duro's immune response.

The ability to generate specific immune responses and immunological memory contributes for resistance to diseases. Thus, in order to address if Curraleiro Pé-duro calves are more likely to generate specific immune response, calves were vaccinated with $M$. bovis-BCG and their immune response were compared to the response of Nellore calves (Nellore).

\section{MATERIALS AND METHODS}

Animals. The Curraleiro Pé-duro (six animals) and Nellore calves (six animals) used in this study were purchased from farms in the State of Goiás, in the Cerrado region of Brazil. They were males, aging between 9-12 months old. Animals were grouped by breed during the pre vaccination assays, and then, randomly allotted in four groups: Vaccinated Curraleiro Pé-duro (VacC), Control Curraleiro Pé-duro (ConC), Vaccinated Nellore (VacN) and Control Nellore (ConN). TST screening was performed using bovine and avian PPDs and according to the National Plan for Control and Eradication of Bovine Brucellosis and Tuberculosis (MAPA 2006). All calves were negative at the beginning of the experiment. The TSTs were performed again 45 days after vaccination. Animals did not receive routine veterinary vaccines during the study. Their health conditions were attested by clinical and routine laboratory tests. All procedures were approved by the Comitê de Ética em Pesquisa - CoEP/UFG, Universidade Federal de Goiás, Goiânia, Brazil.

Vaccination. The vaccinated groups received intradermally, $500 \mu \mathrm{L}$ of BCG-Pasteur strain $\left(10^{6} \mathrm{CFU}\right)$ diluted volume/volume with glycerol. The control groups received $500 \mathrm{~mL}$ of the vehicle (glycerol).

Peripheral blood mononuclear cells (PBMCs). Blood samples $(20 \mathrm{~mL})$ were collected before and 30 days after de vaccination, by jugular vein puncturing using vacuum tubes containing sodium heparin. The peripheral blood mononuclear cells were obtained according to the protocol established by Vesosky et al. (2004). Briefly, heparinized whole blood was centrifuged for the buffy coat isolation. PBMCs were treated with red blood cell lysis buffer ( $\mathrm{NH} 4 \mathrm{Cl}$ and $\mathrm{KHCO} 3$ ) and subsequently resuspended in 1 $\mathrm{mL}$ of sterile supplemented RPMI medium (RPMI 1640 medium GIBCO, $0.15 \%$ sodium bicarbonate, $10 \%$ fetal bovine serum, $1 \mathrm{mg} /$ $\mathrm{mL}$ of L-glutamine 2mM SIGMA, $100 \mathrm{IU} / \mathrm{mL}$ penicillin-streptomycin SIGMA, 1\% sodium pyruvate SIGMA, $1 \mathrm{mg} / \mathrm{mL}$ non essential amino acids 100x SIGMA). Cells were counted using a hemocytometer chamber.

Flow cytometry. PBMCs $\left(2 \times 10^{6}\right.$ cells $\left./ \mathrm{mL}\right)$ of each animal were cultured for 4 hours at $37^{\circ} \mathrm{C}$ in $5 \% \mathrm{CO}_{2}$ with phytohemagglutinin (PHA, $1 \mathrm{mg} / \mathrm{mL}$ ), culture filtered proteins from M. bovis (CFP, $20 \mathrm{mg} / \mathrm{mL}$ ) or medium only, followed by $8 \mathrm{~h}$ of culturing in the pre- 
sence of monensin (5ul/mL-BD Biosciences). Cells were labeled for CD4-FITC (MCA 1654, Serotec), PE-anti CD8 (MCA1654-PE, Serotec) or WC1-FITC (MCA1653F, Serotec), fixed by 4\% buffered paraformaldehyde, permealized using Cytofix/cytoperm reagents (BD Biosciences) according to manufacturers protocols and finally intracellular stained were performed (IFN $\gamma$-FITC, Serotec, Raleigh, NC, USA). Sample was acquired on a BD FACS Calibur (San Jose, California) at the Hospital Araújo Jorge (Cancer Combat Association of the State of Goiás, Brazil). A minimum of 10,000 events within lymphocyte gate (forward and side scatter characteristics) was assessed. Cell populations were analyzed in software Summit 4.2 (Fort Collins Colorado, United States of America). Absolute values of each cell type were determined by the product of the percentages found by flow cytometry analysis and the respective values of WBC of each animal.

Statistical analysis. Data were analyzed by one-way analysis of variance followed by Kruskal-Wallis multiple comparisons test using GraphPAD Software (San Diego, California, United States of America). Differences were considered significant when $p$ value was below 0.05 .

\section{RESULTS}

To understand some mechanisms that might be involved in the Curraleiro Pé-duro natural resistance to infection, the numbers of CD4+ cells in the blood of the two studied breeds were evaluated. PBMCs from Curraleiro Pé-duro and Nellore calves were obtained and the number of CD4+ cells was analyzed by flow cytometry (Fig.1A). Curraleiro Pé-duro calves exhibited higher numbers of $\mathrm{CD} 4^{+}$cells $/ \mathrm{mL}$ in the blood $(2049 \pm 402.3)$ than Nellore calves $(1240 \pm 337)$ (Fig.1B, p<0.05).

Because live attenuated vaccine increases the cellular immune responses (reviewed by Waters et al. 2011) we questioned whether vaccinating with Mycobacterium bovis-BCG would alter the levels of CD4+ cells in the blood of the two breed calves. No differences in the CD4+ cell levels were observed between the unvaccinated and the vaccinated calves. Although the Curraleiro Pé-duro calves maintained the higher levels of $\mathrm{CD}^{+}$cells when compared to Nellore (Fig.1C. VacC: $2371 \pm 202.8$ (mean+-SD), ConC 1653 \pm 184.5 , VacN: $1406 \pm 413.6, p<0.01$, ConN: $1374 \pm 210.4, p<0.05$ ).

Curraleiro Pé-duro animals presented almost twice the level of $\gamma \delta \mathrm{WC}^{+}$cells $(1443 / \mathrm{mL} \pm 384.6$, Fig.2A, $\mathrm{p}<0.05)$ and CD8+ cells $(1258.3 \pm 324.74$, Fig.2B, $\mathrm{p}<0.05)$ observed in Nellore $\left(\gamma \delta W_{C} 1^{+}: 745,5 \pm 67.22\right.$ and CD8: 694.33 \pm 53.47$)$ before vaccination. The $M$. bovis-BCG vaccination did not affect the $\gamma \delta \mathrm{WC}^{+}$and $\mathrm{CD}^{+}$cells levels in any group. For this reason, only the data for the basal levels were described.

As Curraleiro Pé-duro calves show physiologically higher numbers of CD4, CD8 and $\gamma \delta$ positive cells in the blood, we hypothesize that those animals could be able to induce a higher specific immune response to the vaccine than the Nellore calves. In order to address that, thirty days after vaccination, total blood leucocytes were stimulated with BCG and the CD4+IFN- $\gamma^{+}$positive cells were evaluated. CD4 ${ }^{+}$ lymphocytes producing IFN- $\gamma$ in response to mycobacterial antigens differed between vaccinated groups and their respective controls (Fig.3A, p<0,05). As expected, the Curraleiro Pé-duro vaccinated group presented higher levels of
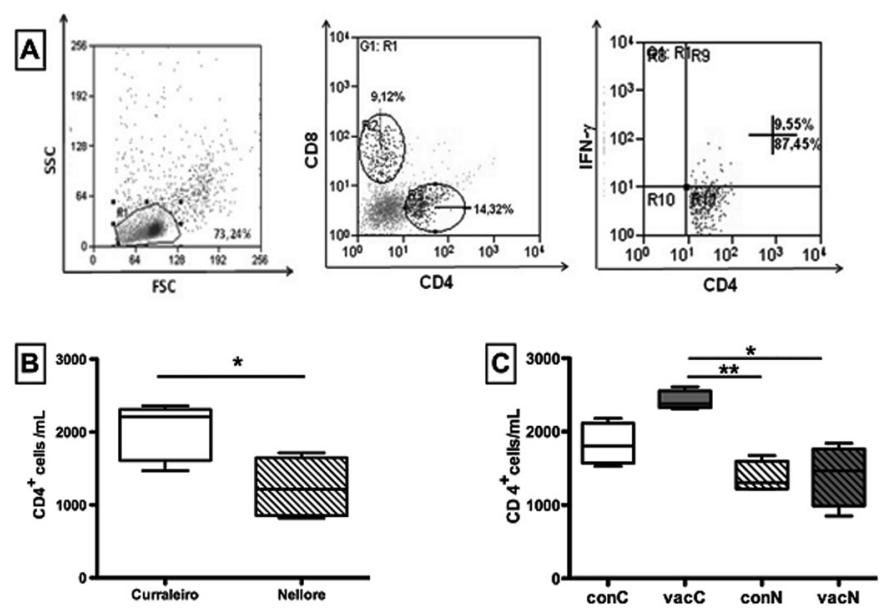

Fig.1. Analysis by flow cytometry of $\mathrm{CD}^{+}$cells of Curraleiro Pé-duro and Nellore PBMCs before and after BCG vaccination. (A) Representative sample of a Curraleiro Pé-duro calf 3 weeks after BCG vaccine: alive lymphocytes (right panel), CD4 ${ }^{+}$ and $\mathrm{CD}^{+}$lymphocytes) (central panel) and CD $4^{+}$IFN $-\gamma^{+}$(left panel). (B) $\mathrm{CD} 4^{+}$cells $/ \mathrm{mL}$ values for Curraleiro Pé-duro and Nellore groups before the vaccination. (C) $\mathrm{CD}^{+}$cells $/ \mathrm{mL}$ values for Curaleiro control (conC), Nellore control (conN), Curraleiro Pé-duro vaccinated (vacC) and Nellore vaccinated groups thirty days after the vaccine administration. Bars represent the medians and theirs standard errors. Absolute numbers are the product of the percentages of each lymphocyte type and the leukogram values of each animal. White bars represent Curraleiro Pé-duro breed. Dashed bars represent Nellore breed. Dark bars represent BCG vaccinated groups, control groups are represented for undashed (Curraleiro Pé-duro) or dashed (Nellore) white bars. *Statistical significance (Kruskal-Wallis, $\mathrm{p}<0.05$ ). ${ }^{* *}$ Statistical significance (Kruskal-Wallis, $\mathrm{p}<0.01$ ).
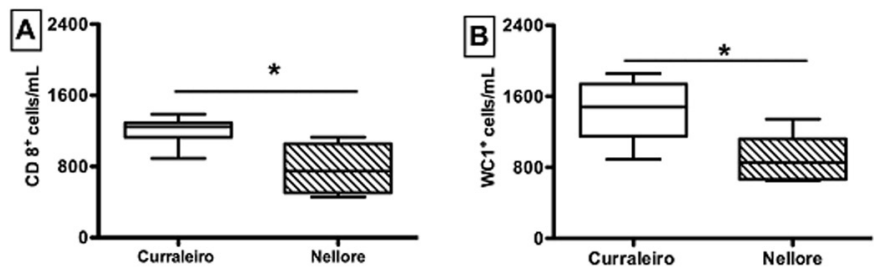

Fig.2. Similar analysis CD8 and $\gamma \delta \mathrm{WC} 1^{+}$lymphocytes of Curraleiro Pé-duro and Nellore calves, before BCG vaccination. (A) $\mathrm{CD}^{+}$cells values for Curraleiro Pé-duro and Nellore calves. (B) $\gamma \delta \mathrm{WC} 1^{+}$cells value for Curraleiro Pé-duro and Nellore calves. Bars represent medians and standard errors. Absolute numbers are the product of the percentages of each lymphocyte type and the leucogram values of each animal. White bars represent Curraleiro Pé-duro breed. Dashed bars represent Nellore breed. *Statistical significance (Kruskal-Wallis, $\mathrm{p}<0.05$ ).

specific CD $4^{+}$IFN- $\gamma^{+}$cells $(202 \pm 44.96)$ than the Nellore vaccinated ones $(112.6 \pm 17.84, \mathrm{p}<0.05)$.

To confirm the specific immune response induced by the vaccination, the animals were evaluated using the tuberculin skin test (TST) that is used as a diagnosis test for bovine TB. All animals used in our study were TST negative, but after the BCG vaccination, both Curraleiro Pé-duro and Nellore increased their TST values (vacC: $2.933 \mathrm{~mm} \pm 1.4$, 

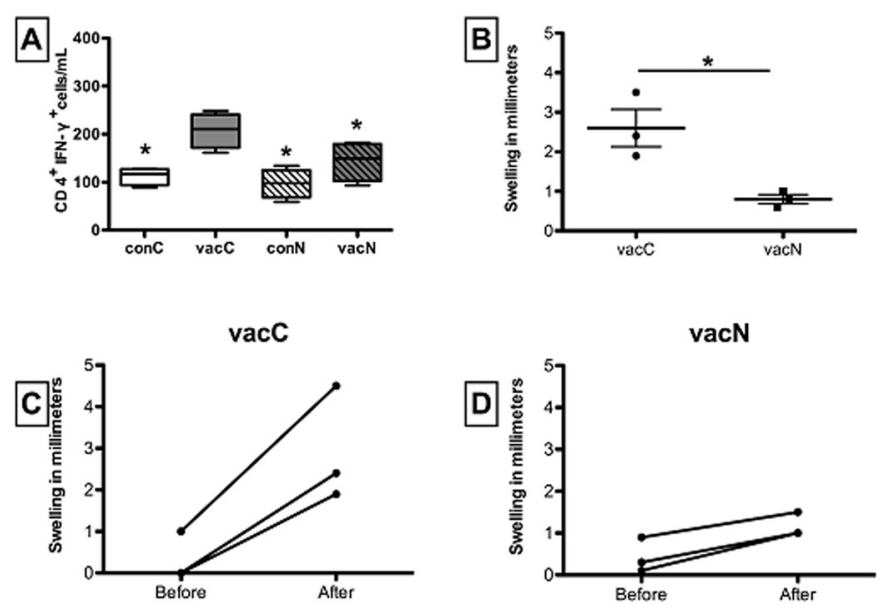

Fig.3. Specific immune response of vaccinated Curraleiro Pé-duro and Nellore calves to BCG. (A) Absolute values of $\mathrm{CD}^{+}$cells producing IFN- $\gamma$ in response to CFP-10 in vitro stimulation. (B) Increasing on Tuberculin Skin Test response of Curraleiro Pé-duro vaccinated (vacC) and Nellore vaccinated (vacN) calves (TST swelling 45 days post BCG vaccination - TST before vaccination). (C) Tuberculin Skin Test evolution on vaccinated Curraleiro Pé-duro (vacC) group before and 45 days after the BCG vaccination. (D) Tuberculin Skin Test evolution on vaccinated Nellore (vacN) group before and 45 days after the BCG administration. Absolute cell numbers are the product of the percentages of each lymphocyte type and the leukogram values of each animal. White bars represent Curraleiro Pé-duro breed. Dashed bars represent Nellore breed. Dark bars represent BCG vaccinated groups, control groups are represented for dashed (Nellore) or undashed (Curraleiro Pé-duro) white bars. *Statistical significance (in A: Signinficance between Curraleiro Pé-duro vaccinated group and the all the others groups (Kruskal-Wallis, $\mathrm{p}<0.05$ ).

vacN: $1.167 \mathrm{~mm} \pm 0.29$, Fig.3C and 3D respectively). Likewise, the Curraleiro Pé-duro calves presented higher increases in their TST test than Nellore calves (Fig.3B, p<0.05).

\section{DISCUSSION}

Curraleiro Pé-duro breed is considered resistant to extreme conditions of breeding, management, and to several infections but minimal scientific data on these animals have been done before. In this work, we show for the first time the blood levels of CD4, CD8 and $\gamma \delta$ WC1 lymphocytes from those animals and its specific immune response elicited after Mycobacterium bovis-BCG vaccination. When compared to an Indian breed (Nellore) well known for its resistance, Curraleiro Pé-duro showed greater induction of specific immune response after BCG vaccination

Although the resistance to a specific pathogen is better accessed after challenging animals with the pathogenic microorganism, carrying out in vivo infection studies is often unwieldy. The majority of the endemic diseases are under strict World Organization for Animal Health (OIE) control and a suitable biosafety environment to study infection of large ruminants with biohazard agents is still lacking in Brazil. To circumvent this problem we opted to use a live attenuated vaccine ( $M$. bovis BCG, Pasteur strain) avoiding any environmental problems such as infection of others animals or workers. In this scenario BCG vaccination was useful to compare immune responses of bovines.

In spite of macrophages being the first cells to encounter the tuberculosis pathogens and their capacity to phagocyte and destroy bacteria, mycobacteria may reside/ replicate within their phagosome (Baena \& Porcelli 2009, Behar et al. 2010). Therefore, the main cell type correlated with resistance after TB infection is the CD4 lymphocytes. Several authors confirmed the importance of this population in disease development, by showing that CD4 deficient mice and human with low CD4 counts are more susceptible to tuberculosis (Behar et al. 1999, Derrick. et al. 2007, Lodi et al. 2013). Our results showed that Curraleiro Pé-duro animals have, physiologically, higher levels of CD4 cell what could facilitate their response to TB and other intracellular pathogens. Also, our results showed the greater ability of Curraleiro Pé-duro animals to generate response with Th1 bias (Fig.3A).

The interaction between pathogen and host is a line defining resistance and occasionally the immune system is subverted, and if lower specific immune response after vaccination occurs it will reflect in a poor protection status. The specific IFN- $\gamma$ production is often used for accessing vaccine responses. In TB context, however, the IFN- $\gamma$ is also correlated with lesion scores (i.e severity of disease) and has been used as a diagnostic tool, in enzyme-linked immunosorbent spot (ELISpot) assay and in blood-based in vitro laboratory test, as the Bovigam test (Vordermeier et al. 2006, Whelan et al. 2011,). The release of IFN- $\gamma$ in infected cattle may be caused by the bacterial burden during later stages of infection, after the immune control of the pathogen has failed, leading to the destructive effects of Th1 response on tissues. Notwithstanding the negative effects that IFN- $\gamma$ release may cause, the specific production of IFN- $\gamma$ is a parameter widely used in vaccine studies (Skinner et al. 2003, Waters et al. 2009, De Souza et al. 2012, Hope et al. 2011 ) because in mice, IFN- $\gamma$ production seems to be substantial for protection. Mice in which the IFN- $\gamma$ gene was disrupted were unable to contain or control a normally sublethal dose of M. tuberculosis. Also, macrophages from these mice have impaired activation, but the treatment with recombinant IFN- $\gamma$ slows their rapidly progression of disease (Cooper et al. 1993, Flynn et al. 1993).

Although, cellular immune responses in calves also activate $\gamma \delta$ and $\mathrm{CD}^{+}$cells (Rhodes et al. 2001, Villarreal-Ramos et al. 2003, Siddiqui et al. 2012), Blanco et al. (2009) showed that CD4 cells are strongly stimulated by mycobacterium antigens in infected cattle, and that CD8 T lymphocytes are stimulated with lower intensity. Similar trends were observed for Curraleiro Pé-duro and Nelore breeds, once $\mathrm{CD}^{+}$antigen specific cells overwhelmed the response compared to $\mathrm{CD} 8^{+}$cells.

The TST reaction to mycobacterial antigens is an important diagnostic tool in human and animals. Yet, the use of the skin test as a clinical indicator of successful BCG-induced protective immunity is controversial. Whelan et al. (2011) found that the loss of the TST reaction after $B C G$ vaccination was not correlated with loss in protection on neonate calves. The TST and IFN- $\gamma$ responses are both 
predictive of infection, however the relationship between the two responses is not so clear. Cooper et al. (1993) observed that mice lacking IFN- $\gamma$ gene and infected with $M$. tuberculosis are able to mount significant TST swelling responses, in despite of the divesting effect of IFN- $\gamma$ deletion on protective immunity against tuberculosis. Whealan et al. (2011) found that some BCG vaccinated calves tend to loose their TST responses over time, but kept similar levels of cells specifically producing IFN- $\gamma$ (accessed by the ELISpot assay). Here, we show that Curraleiro Pé-duro calves retained both IFN- $\gamma$ and TST responses. It may indicate that Curraleiro Pé-duro also had higher levels of other cytokines or chemokines or even some differences on the innate immunity, causing the early/stronger migration of cells to antigen site on the skin of vaccinated animals. Those parameters and the genetic basis of the differences found on Curraleiro Pé-duro breed were not accessed at this point and further studies are needed. Immunity to TB is a complex process and no singular mechanism or cell type is sufficient to kill mycobacterium in vivo (Thakur et al. 2012).

\section{CONCLUSIONS}

The data showed that Curraleiro Pé-duro animals have greater levels of CD4, CD8 and $\gamma \delta$ lymphocytes, and have greater ability to specifically respond to BCG.

These findings suggest that Curraleiro Pé-duro may have genetic traits leading to resistance to Mycobacterium bovis infection, and perhaps other infections in which Th1 response is advantageous.

Such characteristic deserves further investigation, which may constitute an important genetic resource, serving as alternative for cross-breeding studies.

Therefore, the Curraleiro Pé-duro should be preserved due its resistance characteristics or historical value.

Acknowledgments.- This study was supported by Fundação de Amparo à Pesquisa do Estado de Goiás (FAPEG), M.F.M and J.R.L were supported by research fellowships from Conselho Nacional de Desenvolvimento Científico e Tecnológico (CNPq) and Coordenação de Aperfeiçoamento de Nível Superior (CAPES), respectively.

\section{REFERENCES}

Abelli A.M.G., Nakata L.C., Andréo R., Coutinho L.L., Oliveira M.C.S., Amarante A.F.T., Furlong J., Zaros L.G. \& Regitano L.C.A. 2010. mRNA profile of Nellore calves after primary infection with Haemonchus placei. Vet. Parasitol. 176:195-200.

Azevêdo D.M.M.R., Alves A.A., Feitosa F.S., Magalhães J.A. \& Malhado E.C.H.M. 2008. Adaptabilidade de bovinos da raça Pé-Duro às condições climáticas do Semi-Árido do estado do Piauí. Archs Zootec. 57:513-523.

Baena A. \& Porcelli S.A. 2009. Evasion and subversion of antigen presentation by Mycobacterium tuberculosis. Tissue Antigens 74:189-204.

Behar S.M., Dascher C.C., Grusby M.J., Wang C.R. \& Brenner M.B. 1999. Susceptibility of mice deficient in CD1D or TAP1 to infection with Mycobacterium tuberculosis. J. Exp. Med. 189:1973-1980.

Behar S.M., Divangahi M. \& Remold H.G. 2010. Evasion of innate immunity by Mycobacterium tuberculosis: is death an exit strategy? Natl Rev. Microbiol. 8:668-674.

Bianchini E., McManus C., Lucci C.M., Fernandes M.C.B., Prescott E., Mariante A.S. \& Egito A.A. 2006. Características corporais associadas com a adaptação ao calor em bovinos naturalizados brasileiros. Pesq. Agropec. Bras. 41:1443-1448.
Blanco F.C., Schierloh P., Bianco M.V., Caimi K., Meikle V., Alito A.E., Cataldi A.A., Sasiain M. del C. \& Bigi F. 2009. Study of the immunological profile towards Mycobacterium bovis antigens in naturally infected cattle. Microbiol. Immunol. 53:460-467.

Buddle B.M., Wedlock D.N., Denis M. \& Skinner M.A. 2005. Identification of immune response correlates for protection against bovine tuberculosis, Vet. Immunol. Immunopathol. 108:45-51.

Buddle B.M. 2010. Tuberculosis vaccines for cattle: the way forward. Expert Rev. Vaccines 10:1121-1124.

Chan P.C., Yang C.H., Chang L.Y., Wang K.F., Kuo Y.C., Lin C.J., Lee S.W., Hsueh P.R., Fang C.T. \& Huang L.M. 2013. Lower prevalence of tuberculosis infection in BCG vaccinees: a cross-sectional study in adult prison inmates. Thorax 68:263-268.

Cooper A.M., Dalton D.K., Stewart T.A., Griffin J.P., Russell D.G. \& Orme I.M. 1993. Disseminated tuberculosis in interferon gamma gene-disrupted mice. J. Exp. Med. 178:2243-2247.

Derrick S.C., Evering T.H., Sambandamurthy V.K., Jalapathy K.V., Hsu T., Chen B., Chen M., Russell R.G., Junqueira-Kipnis A.P., Orme I.M., Porcelli S.A., Jacobs Jr W.R. \& Morris S.L. 2007. Characterization of the protective T-cell response generated in CD4-deficient mice by a live attenuated $M y$ cobacterium tuberculosis vaccine. Immunology 120:192-206.

De Sousa E.M., Costa A.C., Trentini M.M., Araújo Filho J.A., Kipnis A. \& Junqueira-Kipnis A.P. 2012. Immunogenicity of a fusion protein containing immunodominant epitopes of Ag85C, MPT51, and HspX from Mycobacterium tuberculosis in mice and active TB infection. PLoS ONE 10:e47781.

FAO 1995. World Watch List for Domestic Animal Diversity. $2^{\text {nd }}$ ed. Food and Agriculture Organization, Rome, p.495-505. Available in <http:// www.fao.org/wairdocs/lead/x6197e/x6197e00.htm>

Fioravanti M.C.S., Juliano R.Q., Costa L.G., Abud L.J., Cardoso V.S., Carpio M.G. \& Costa M.F.O. 2011. Conservación del bovino Curraleiro: cuantificación del censo y caracterización de los criadores. Animal Genetic Resources 48:109-116.

Flynn J.L., Chan J., Triebold K.J., Dalton D.K., Stewart T.A. \& Bloom B.R.J. 1993. An essential role for interferon gamma in resistance to Mycobacterium tuberculosis infection, J. Exp. Med. 178:2249-2254.

Hope J.C., Thom M.L., McAulay M., Mead E., Vordermeier H.M., Clifford D., Hewinson R.G. \& Villarreal-Ramos B. 2011. Identification of surrogates and correlates of protection in protective immunity against Mycobacterium bovis infection induced in neonatal calves by vaccination with M. bovis BCG Pasteur and M. bovis BCG Danish. Clin. Vaccine Immunol. 18:373-379.

Kaufmann S.H.E., Baumann S. \& Nasser Eddine A. 2006. Exploiting immunology and molecular genetics for rational vaccine design against tuberculosis. Int. J. Tuberc. Lung Dis. 10:1068-1079.

Lodi S., Del Amo J., D’Arminio Monforte A., Abgrall S., Sabin C., Morrison C., Furrer H., Muga R., Porter K. \& Girardi E. 2013. Risk of tuberculosis following HIV seroconversion in high-income countries. Thorax 68:207-213.

MAPA 2006. Programa Nacional de Controle e Erradicação da Brucelose e da Tuberculose: manual técnico. Departamento de Defesa Animal, MAPA/DAS/DSA, Brasília, p.51-65.

McManus C., Paludo G.R., Louvandini H., Garcia J.A.S., Egito A.A. \& Mariante A.S. 2005. Heat tolerance in naturalised cattle in Brazil: physical factors. Archs Zootec. 54:453-458.

McManus C., Castanheira M., Paiva S.R., Louvandini H., Fioravanti M.C.S., Paludo G.R., Bianchini E. \& Corrêa P.S. 2011. Use of multivariate analyses for determining heat tolerance in Brazilian cattle. Trop. Anim. Health Prod. 43:623-630.

Mariante A.S. \& Egito A.A. 2002. Animal genetic resources in Brazil: result of five centuries of natural selection. Theriogenology 57:223-235.

Mariante A.S. \& Cavalcante N. 2006. Animals of the Discovery: domestic breeds in the history of Brazil. 2 ${ }^{\underline{a}}$ ed. Empresa Brasileira de Pesquisa Agropecuária, Brasília.

Mariante A.S \& Bem A.R. 1992. Animal Genetic Resource Information. FAO, Rome, 10:7-26. Available in <ftp://ftp.fao.org/docrep/fao/012/ u8945t/u8945t01.pdf> 
Moraes J.M., Brito L.A.B., Moura V.M.B.D., Ribeiro C.S., Guimaraes V.Y., Andrade D.F., Lobo J.R. \& Fioravanti M.C.S. 2009. Immunophenotyping and quantitative evaluation of circulating lymphocytes of cattle of the Curraleiro Pé-duro breed. Pesq. Agropec. Bras. 29:339-344.

Moura M.I., Torres T.F., Monteiro E.P., Neiva A.C.G.R., Cardoso W.S. \& Fioravanti M.C.S. 2011. Evolution of the Curraleiro Pé-duro cattle herd reintroduced in native savannah in the northeast of Goiás, Brazil. Actas Iberoamericanas de Conservación Animal 1:123-126.

Nema V. 2012. Tuberculosis diagnostics: challenges and opportunities. Lung India 29:259-266.

Oliveira M.C.S., Alencar M.M., Chagas A.C.S., Giglioti R. \& Oliveira H.N. 2009. Gastrointestinal nematode infection in beef cattle of different genetic groups in Brazil. Vet. Parasitol. 166:249-254.

Rhodes S.G., Hewinson R.G. \& Vordermeier H.M. 2001. Antigen recognition and immunomodulation by gamma delta $\mathrm{T}$ cells in bovine tuberculosis. J. Immunol. 166(9):5604-5610.

Serrano G.M.S., Egito A.A., McManus C. \& Mariante A.S. 2004. Genetic diversity and population structure of Brazilian native bovine breeds. Pesq. Agropec. Bras. 39:543-549.

Serrano G.M.S., Egito A.A., McManus C. \& Mariante A.S. 2005. Genetic population structure of Brazilian bovine Breeds inferred by RAPD markers. Archs Zootec. 54: 09-414.

Siddiqui N., Price S. \& Hope J. 2012. BCG vaccination of neonatal calves: potential roles for innate immune cells in the induction of protective immunity. Comp. Immunol. Microbiol. Infect. Dis. 35(3):219-26.

Skinner M.A., Buddle B.M., Wedlock D.N., Keen D., Lisle G.W., Tascon R.E., Ferraz J.C., Lowrie D.B., Cockle P.J., Vordermeier H.M. \& Hewinson R.G. 2003. A DNA prime-Mycobacterium bovis BCG boost vaccination strategy for cattle induces protection against bovine tuberculosis. Infect. Immun. 71: 4901-4907.

Thakur A., Pedersen L.E. \& Jungersen G. 2012. Immune markers and cor- relates of protection for vaccine induced immune responses. Vaccine 30:4907-4920.

Thom M.L., McAulay M., Vordermeier H.M., Clifford D., Hewinson R.G., Villarreal-Ramos B. \& Hope J.C. 2012. Duration of immunity against Mycobacterium bovis following neonatal vaccination with bacillus CalmetteGuérin Danish: significant protection against infection at 12, but not 24, months. Clin. Vaccine Immunol. 19:1254-1260.

Vesosky B., Turner O.C., Turner J. \& Orme I.M. 2004. Gamma interferon production by bovine gamma delta $\mathrm{T}$ cells following stimulation with mycobacterial mycolylarabinogalactan peptidoglycan. Infect. Immun. 72:4612-4618.

Villarreal-Ramos B., McAulay M., Chance V., Martin M., Morgan J. \& Howard C.J. 2003. Investigation of the role of CD8+ T cells in bovine tuberculosis in vivo. Infect. Immun. 71:4297-303.

Vordermeier H.M., Chambers M.A., Buddle B.M., Pollock J.M. \& Hewinson R.G. 2006. Progress in the development of vaccines and diagnostic reagents to control tuberculosis in cattle. Vet. J. 171:229-244.

Waters W.R., Palmer M.V., Nonnecke B.J., Thacker T.C., Scherer C.F., Estes D.M., Hewinson R.G., Vordermeier H.M., Barnes S.W., Federe G.C., Walker J.R., Glynne R.J., Hsu T., Weinrick B., Biermann K., Larsen M.H. \& Jacobs Jr W.R. 2009. Efficacy and immunogenicity of Mycobacterium bovis DeltaRD1 against aerosol M. bovis infection in neonatal calves. Vaccine 27:1201-1209.

Waters W.R., Palmer M.V., Thacker T.C., Davis W.C., Sreevatsan S., Coussens P., Meade K.G., Hope J.C. \& Estes D.M. 2011. Tuberculosis immunity: opportunities from studies with cattle. Clin. Develop. Immunol.: 768542. 10.1155/2011/768542 [doi].

Whelan A.O., Coad M., Upadhyay B.L., Clifford D.J., Hewinson R.G. \& Vordermeier H.M. 2011. Lack of correlation between BCG-induced tuberculin skin test sensitisation and protective immunity in cattle. Vaccine 29:5453-5458. 